which there can be no doubt, we get the following velocities, taking the shortest lines between Krakatao and the various stations :-

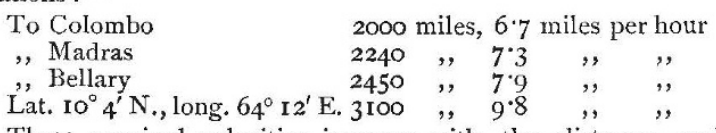

These required velocities increase with the distance, and, taking along with them the rate of forty miles an hour demanded by the Japan observations, it is difficult to believe that dust could have travelled in these various directions with such different velocities.

There is also the negative evidence that rain-water collected in Madras during the period of the green sun contained no volcanic dust, as far as a careful microscopic examination of the residue could determine it. On the dust hypothesis, too, it is difficult to understand the cessation and reappearance of the phenomenon.

There is some definite evidence on which to base the argument for the water-vapour theory. The observations detailed at the beginning of this paper show that the spectrum of the green sun had the absorption-lines of water-vapour very well marked, and that there was also a general absorption in the red. This absorption might indeed be accounted for by supposing a number of dust particles of a certain size to be suspended in the air ; but a precisely similar absorption has been observed when the sunlight traversed the very thick clouds of a violent thunderstorm. The fact that water-vapour may make the sun appear green is proved by the numerous observations of a green sun through the escaping vapour from the funnel of a steamer, and through mist. The abundance of water-vapour in suspension was proved by the very heavy monsoonal rains which followed the appearance of the green sun. In Madras the rainfall was 19.17 inches above the average.

The green sun, although uncommon, is by no means so rare a phenomenon as is generally supposed. Since my attention has been directed to it, I have observed it several times, very conspicuously on May I 3 and $I_{4}$. But there is a reason why $i$ should not appear much more frequently, and that is that, supposing the absorption producing it to be brought about by an abnormal amount of water-vapour, that vapour must be in suspension, while in fact it generally partly precipitates, forming clouds that conceal the sun as its hour of setting approaches. An interesting question arises as to whether the clearness of the atmosphere, when a large amount of aqueous vapour was in sus. pension during the appearance of the green sun, might not be due to an abnormal electrical state. The numerous and intense thunderstorms that occurred during the period showed that all the clouds were highly electrified, and the electrometer observations already referred to also indicated an unusually electrified atmosphere; but I am not prepared to lay much stress on the electrometer readings until I have made a more extended series of observations in ordinary weather.

The presence of abundance of aqueous vapour at the time of the appearance of the green sun may be explained naturally enough by the setting in of the moist monsoon currents in the upper parts of the atmosphere, or at least by the conflict between the north-east and south-west monsoons, which had commenced by that time.

It is not at all improbable that the Krakatao eraption had some influence on the direction of these currents. The ejection of a large volume of heated vapour would produce a centre of low pressure and set up a cyclonic influx of air from other places. It is possible that the peculiarities obscrved in the Indian barometric curves for some time after the eruptions were due to this cause. The cruption, too, might have something to do with the electrical conditions; for it is known from Prof. Palmieri's observations that electricity is generated by the cruptions of Vesuvius.

I was once inclined to view with favour the theory of the appearances being produced by cosmic dust, stupposing the dust to act either by its mere presence or by forming nuclei for absorption; but considerations of the amount of solar radiation during the greenness have shaken my faith in this explanation.

We must, therefore, I think, give up any theory involving the presence of sufficient dust to render the sun green. Whether or not the following sunset glows were due to dust I cannot discuss here; but I would point out that an amount of dust sufficient to produce these effects would probably not materially affect the transparency of the atmosphere.

\section{EDUCATION, SCIENCE, AND ART}

THE Select Committee of the IIouse of Commons appointed to consider how the Ministerial responsibility under which the votes for Education, Science, and Art are administered may be best secured, have agreed to the following report :-

Your Committee have examined the present and several former Presidents and Vice-Presidents of the Council, Secretaries to the Lord Lieutenant of Ireland, permanent heads of the Education Department in London, the present Resident Commissioner of National Education in Ireland, and also other gentlemen conversant with the matters referred to your Committee. They have also considered the evidence taken before the Select Committee appointed in 1865 and 1866 to inquire into the constitution of the Committee of Council on Education.

The first question considered by your Committee was whether primary cducation in Great Britain and in Ireland should be placed under one supervising Minister. Your Committee are satisfied that under present circumstances it would be undesirable to disturb the existing arrangements as to the Ministerial responsibility for primary education in Ireland.

They a e also of opinion that primary education in England and Scotland should be under the control of the same Minister.

The Lord President of the Council, almost always a peer, is nominally the head of the Education Department for Great Britain.

The Vice-President represents the department in the House of Commons, and really transacts almost all the business requiring authority above that of the permanent officials.

Your Committee are of opinion that this arrangement is neither logical nor convenient. They see no sufficient reason why there should be any more real connection between the Education Department and the Privy Council than betwe $n$ the Board of Trade and the Privy Council ; but as it may be convenient that the Mini ter for Education should have occasionally the assistance, whether as to English or Scotch Education, of other Privy Councillors specially summoned for consultation with him, they recommend that a Board of (or Committee of Ccuncil for) Education should be constituted under a President, who should be the real as well as nominal Minister, in this respect holding a position like that of the President of the Board of Trade. Hitherto there has been a separate Scotch Department of the Privy Council, and your Committee consider that it would be well to have a distinct permanent secretary appointed for Scotland, responsible to the Minister of Education.

Whether the Minister of Education should always be a member of the Cabinet or of the House of Commons, and what should be his salary, are questions upon which it is hardly within the province of your Committee to make absolute recommendations. They think, however, that the duties of this Minister should be recognised as not less important than those of some of the Secretaries of State.

The Minister of Education should have the assistance of a Parliamentary Secretary, able to sit in either House of Parliament.

While on the whole preferring the plan they have suggested, your Committee do not deny that there are objections to the constitution of an administrative department in the form of a board which has no real existence. The permanent secretary and his assistants bind by their signature, nominally the board, really, the political chief.

This system, it must be admitted, tends to lessen the direct control and responsibility to Parliament and the public which is apparent in the office of a Secretary of State.

The second question discussed by your Committee was whether, and if so what, authority should be exercised by the Minister of Education over endowed schools. Your Committee recommend that when schemes for endowed schools, whether in England or in Scotland, have come into operation, the Minister of Education should have full authority to call on the governing bodies to furnish him with such reports and information as he may require, and to direct any inquiries or inspection to be made which he may deem necessary.

$\Lambda$ s to public schools, your Committee recommend that the Minister of Education should be authorised to call for such reports and information as he may require from the governing bodies, but they are not of opinion that his powers should extend to directing inspection.

With respect to the Universitics in Great Britain receiving grants charged on the votes of Parliament or on the Consolidated 
Fund, the Minister should be authorised to require from them an annual report in such form as he may order.

Your Committee have not taken any evidence as to reformatory and industrial schools, considering that these have so recently formed the subject of an inquiry by a Royal Commission, the report and recommendations of which are before Parliament. They see no reason for altering the present responsibility for workhouse schools or for the primary schools connected with the Army, the Navy, or the Marines. The responsibility for the administration of the votes for military and naval colleges do not appear to come within the reference to your Committee.

Your Committee see no reason to disturb the existing arrangements as to the supervision of the Science and Art Department.

There are various miscellaneous votes for science and art, such as those for scientific research, distributed through the Royal Society, votes for meteorology, and votes in aid of the Royal Society of Edinburgh and the Royal Irish Academy. These votes, your Committee think, should be moved by the Minister of Education, and reports, when necessary, should be made to him.

Your Committee do not propose to bring the British Museum and the National Gallery into closer relations with Her Majesty's Government than those now existing, with this exception, that, in their opinion, the Minister of Education and the Parliamentary Secretary should be ex officio trustces of each of those institutions. The President of the Council, your Committee notice, is now an ex officio trustee of the British Museum. The House of Commons would then look to the Education Department for explanations when the votes for the British Muscum and the National Gallery are discussed in Committee of Supply.

The Committee, of which the Chancellor of the Exchequer was chairman, included, among other members, Sir J. Lubbock, Mr. Salt, Mr. Raikes, Sir L. Playfair, Mr. S. Morley, Mr. Pell, Mr. Sclater-Booth, and Mr. J. Collings.

\section{THE MARINE BIOLOGICAL ASSOCIATION}

THE Council of the Marine Biological Association adopted last :-the following statements at its meeting held on July 25

\section{MEMoRANDUM No. I}

The Marine Biological Association was founded in March, $\mathbf{r} 884$, at a meeting held in the apartments of the Royal Socicty of London, Prof. Huxley, P.R.S., in the chair. Its officers and council include the leading naturalists of the country, as well as noblemen and others who took an active part in the late Fisheries Exhibition. H.R.H. the Prince of Wales has consented to be Patron of the Association, and has given evidence of the importance which he attaches to the success of its objects by contributing a handsome donation to its funds. The following is a list of the Executive of the Association :-

President : Prof. Huxley (President of the Royal Society). Vice-Presidents: The Duke of Argyll, K.G.; the Duke of Sutherland, K.G. ; the Marquis of Hamilton; the Earl of Dalhousie, K.T. ; Lord Walsingham (Trustee of the British Museum of Natural History); Prof. Allmann, F.R.S.; Sir John St. Aubyn, Bart., M.P.; Edward Birkbeck, M.P. (Chairman of the Executive Committee of the International Fisheries Exhibition); George Busk, F.R.S.; W. B. Carpenter, C.B., M.D., F.R.S.; W. II. Flower (Director of the British Museum of Natural History); J. Gwyn Jeffreys, F.R.S.; Sir John Lubbock, Bart., M.P. (President of the Linnean Society).

Council: Prof. Moseley, F.R.S. (Oxford), Chairman; C. Spence Bate, F.R.S. (Plymouth); Prof. Jeffrey Bell, F.Z.S. (British Museum) ; W. S. Caine, M.P. ; W. T. Thiselton Dyer, C.M.G., F.R.S. (Royal Gardens, Kew); John Evans, D.C.L. (Treasurer, R.S.); A. C. L. G. Günther, F.R.S. (British Museum) ; Prof. Herdman (Liverpool); E. W. H. Holdsworth ; Prof. McIntosh (St. Andrew's); Prof. Milnes Marshall (Manchester) ; Sir Philip Cunliffe Owen, K.C.M.G., C.B. ; G. J. Romanes, F.R.S. (Secretary of the Linnean Socicty); P. L. Sclater, F.R.S. (Secretary of the Zoological Society); Adam Sedgwick (Cambridge).

Hon. Treasurer: Frank Crisp (Vice-President and Treasurer of the Linnean Society), 6, Old Jewry, E.C.

Hon. Secretary : Prof. E. Ray Lankester, F.R.S., Ir, Wellington Mansions, North Bank, N.W.

The object of the Association is to erect one or more laboraories on the coast of the United Kingdom, where studies may be carried on by naturalists, leading to an improvement in zoological and botanical science, and especially to an adequate acquaintance with the food, habits, spawning, and propagation of our marine food-fishes and shell-fish.

Great scientific and practical results have been obtained in other countries, notably in the United States of America, in Germany, France, and Italy, by studies carried on through such laboratories as the Marine Biological Association proposes to erect in this country. The knowledge which can be thus and thus only gained is precisely that knowledge which is at present urgently needed in order to regulate and improve British Sea Fisheries, and it therefore seems to be not inappropriate that public bodies as well as individuals interested in the progress of natural history science should take in hand the promotion of the first attempt to institute an efficient sea-coast laboratory in these islands.

It is estimated by the Council that a sum of ro,oool. will be required to build and equip an efficient laboratory, and to insure a successful start for the Association. This sum does not include any payment to the naturalists who may conduct the operations of the laboratory, since in the first instance, at any rate, such services will be rendered gratuitously. The money which is now asked for will be expended entirely upon the laboratory, its equipment, and necessary service.

As the result of an appeal to scientific men and their immediate friends the Association has raised a sum of about 2000l. In order to obtain the rest of the money which is required it is necessary to appeal to a wider circle.

The Council of the Association feel that they have undertaken a work of national importance, and therefore confidently appeal to those who have pecuniary resources at their disposal to give them substantial aid in its realisation.

According to the bye-laws of the Association adopted at a meeting of members on June I7, I884, donors of $500 l$, to the Association become governors and permanent members of the Council of the Association. The Council hope that they may reccive some contributions of this amount or of larger sums, and would suggest that it might be found convenient by those who may intend to assign sums of large amount to the Association to do so in the form of a payment of so much a year spread over a term of years.

The donor of 100". to the Association becomes a "Founder" and life member. $\Lambda \mathrm{n}$ annual subscription of $\mathbf{r}$ l. Is., or a composition fee of $\mathbf{I}_{5} l$. I5s., is required of ordinary members. Members of the Association have the right to take part in the government of the $\Lambda$ ssociation by electing the Officers and Council at their annual meeting : they will receive the printed reports of the Association, and enjoy special privileges in the use of the laboratory and its resources.

It is intended to require an entrance fee of $5 l .5 \mathrm{~s}$. from members who join the Association later than June, I 885 .

Signed (on behalf of the Council of the Marine Biological Association),

H. N. Moseley, M.A., F.R.S., Chairman of the Council,

Linacre Professor of Anatomy in the University of Oxford July 25,1884

Memorandum No. II.-Nature of the Building, Management, and Work of the Proposed Marine Laboratory and Experimental Aquarium. - The Council of the Marine Biological Association cannot as yet definitely pledge itsclf as to details, but the following is a sketch of the nature of the building which it proposes to erect, of the probable management of the Laboratory, and of the kind of work which may be expected to be accomplished by its aid.

The most complete institution of the kind is that at Naples, which is supported by contributions from various European States, and is especially subsidised by the German Imperial Government. The buildings, fittings, and boats belonging to this institution have cost 20,000 . It is proposed to slart such an institution in this country with half this sum.

I. Building. - The first laboratory of the Marine Biological Association will probably be erected on the shore of Plymouth Sound. Plymouth is not only by its natural features one of the best possible localities for the purpose, but a Committee of the Town Council has offered to the Association a suitable site free of cost and a contribution of $1000 l$.

With regard to the building, the Council of the Marine Biological Association contemplate erecting a solid brick structure 